\title{
The Influence of Phase the Organizational Life Cycle on Organizational Structure Management and Transaction Costs
}

\author{
Elina A. Gurianova ${ }^{1}$, Igor N. Gurianov ${ }^{2,3}$ \& Svetlana A. Mechtcheriakova ${ }^{2,3}$ \\ ${ }^{1}$ Department of General Management, Kazan Federal University, Kazan, Russian Federation \\ ${ }^{2}$ Securities department, OAO “Tatneftekhiminvest-holding”, Kazan, Russian Federation \\ ${ }^{3}$ Department of General Management, Kazan Federal University, Kazan, Russian Federation \\ Correspondence: Elina A. Gurianova, Department of General Management, Kazan Federal University, Kazan, \\ Russian Federation. E-mail: elinagur@mail.ru
}

Received: June 17, 2014 Accepted: July 12, 2014 Online Published: September 28, 2014

doi:10.5539/ass.v10n20p137

URL: http://dx.doi.org/10.5539/ass.v10n20p137

\begin{abstract}
The aim of this work is to establish the relationship between the stages in the organizational life cycle, management structure and the structure of the transaction costs of the organization. This article discusses the life cycle stages. Are described the major characteristics of each stage, including the features of the organizational structure of the management. For each stage in the life cycle of the organization is different structure of transaction costs, because there are distinctions of the development priorities of the organization. In this article is analyzing the stages of the life cycle from the point of view of transaction costs. Adjustment of structure and the level of transaction costs are achieved by changing the organizational structure of the management, management methods. These operations will enable the organization to make the most effective use of its resources to achieve the objectives of the organization. For each stage of the life cycle is a specific type of organizational management structure. In the article was done the analysis of transaction cost of the enterprise of food industry of the Russian Federation in phases of the organizational life cycle. Draws conclusions on the causes of changes in their structure. Study of the level and structure of transaction costs the organization allows to do analysis of the effectiveness of the functioning of the organization. This analysis allows seeing bottlenecks in the development of the structure of internal and external communications of the organization. That ultimately gives the opportunity to develop a strategy to improve the efficiency of the organization.
\end{abstract}

Keywords: organizational life cycle, transaction costs, the management efficiency, organizational structure of management

\section{Introduction}

Transaction costs are accompanying the activities of any organization and they are often very significant. If the organization will be able to reduce costs without compromising the achievement of organizational goals, this would enhance the effectiveness of the organizational structure of the management as a whole. The size and structure of the transaction costs depends on the stage of the life cycle of the organization and the type of organizational structure of the management.

To improve the effectiveness of the organization, managing director of the company should set itself the task of defining the structure, dynamics, and the sources of growth in transaction costs at each stage of the life cycle of the organization (Bagautdinova, 2014).

Development of the concept of the life cycle is associated with the theoretical concepts of the cyclical fluctuations in the economy, the basic provisions of the systems approach, and research in the field of management, organization theory, organizational behavior, and other sciences.

The best known research on the organizational life cycle are of the following authors: Greiner (1972), Adizes (1979), Kimberly (1979), Miller and Friesen (1984), Lester and Parnell (2006), Hanks (1990).

One of the most popular models of the life cycle has been proposed Greiner (1972) in an article "Evolution and Revolution as Organizations Grow" published in the Harvard Business Review in 1972. In 1979, the magazine Organizational Dynamics Adizes (1979) for the first time presented his ten-step of the lifecycle model, which is 
still relevant today.

From the 80 years of the 20 century, an interest is growing to the practical application of the concept of life-cycle management of the organization. Works Cameron and Whetton (1981), Miller and Friesen (1984), Mintzberg (1984), Hanks (1990), Drazin and Kazanjian (1990), Gupta and Chin (1994), Serrasqueiro and Ferrera (2003), Petrauskiene and Pundziene (2004), Lester and Parnell (2008), Zhipeng (2006) are devoted on empirical research life cycle and identify the quantitative and qualitative characteristics of the stages of development of the organization.

However, these works do not consider life-cycle stages of the organization in terms of the impact on transaction costs. In this article the authors are using the developed by them method (Gurianova, 2013) of the analysis of the organizational life cycle from the perspective of transaction costs and the characteristics of the organizational structure of the management. Features of the proposed method are demonstrated on the example of the food industry of the Russian Federation.

\section{Methodology}

Without an analysis of transaction costs, it is impossible to understand how the elements of the organizational structure of the company were interacted and how to localize the problem. The size of the transaction costs depends on: the type of organizational structure, the list of offered to market products and services, the suppliers of raw materials. Transaction cost analysis from the perspective of organizational life cycle necessary to the head of the Organization to concentrate on solving the problems that are defined to current stage of development of the organization.

The used economic model considers the transaction costs are treated as value, i.e. the value of the resources spent on the transaction. It follows that the costs can be found the cash equivalent.

For ease of identification and analysis we have to do classification of transaction costs. Within the used economic model we have to divide external transaction costs and internal transaction costs.

To the external transaction costs of the organization is belonging: the cost of search and processing of external information; the costs of negotiating and concluding contracts; the costs to avoid opportunistic behavior.

To the internal transaction costs of the organization is belonging: the cost of collection, storage, and analysis of internal information (Fakhrutdinova, 2014); the costs of coordination; control costs (including the costs to avoid opportunistic behaviors in the internal environment of the organization).

\subsection{The Stages of Organizational Life Cycle}

This article examines five phases of organizational life cycle: stage of introduction, stage of growth, stage of maturity, stage of saturation, stage of recession.

\subsubsection{Stage of Introduction}

During Stage of introduction, the founders of the organization identify unsatisfied consumer needs or social needs. The organization is in a formation stage. The founders are formed the organizational life cycle. Goals still are the indistinct. The organization, having a high creative potential, is focused on survival. At this stage, the mission of the organization is forming. At this point the organization needs regular inflow of cash.

Management of the organization is carried out the founders of the organization and his starting original team. Prescriptive method guide management is often used, which requires quick and careful monitoring (Hajrullina, 2014). For those who during this period, the works in the organization, is characterized by high cohesion and interaction. At this stage there is no strict responsibilities assigned to each employee.

The company only responds to the opportunities provided by the external environment, it cannot foresee them. The company operates through trial and error.

\subsubsection{Stage of Growth}

At the stage of growth are stabilizing cash flows and the activities of the organization. The task of this period-quick success. All the work is done is often stretched to the limit in order not to lose the tempo increasing success. The energy and resources of the organization are focused on the fight with competitors (Hajrullina, 2014).

During this period, the growth chart is generally not stable, for it sharp jumps are characteristic. Such economic processes are adjusted: planning, developing budgeting and forecasting (Kirshin, 2008).

The main goal at this stage is to gain market share and improve the quality of activities. For growth acceleration 
organization is hiring of new specialists, owing to that are taking place conflicts with old employees. The founders are now performing the role of line managers, not entrepreneurs, conducting systematic planning, coordination, management and monitoring.

\subsubsection{Stage of Maturity}

The distinctive signs of stage of maturity-expansion and diversification. Structural units are formed, the results of which activity are measured by the profit. The main features of the organization at the stage of maturity: the availability of official duties, job descriptions, the organizational structure, planning and developed plans, result orientation.

At this stage the Organization has the goal of balanced growth (Sarkin, 2014). The structure, coordination, stability and control should be as important as innovation, improvement of all elements of the Organization and decentralization. Control method used in the organization-centralized. At this stage, a great importance is given to the management of new products, markets and technology, and the qualification skills of administrative personnel.

At this point, begin to show a trend of bureaucracy, the struggle for power, the desire to succeed at any cost.

\subsubsection{Stage of Saturation}

Stage of saturation is the beginning stage of aging in the organization life cycle. The company still strong, but begins to lose flexibility. Despite the fact that income level is acceptable, the rate of growth is slowing. The organization can deviate from their original purposes under the influence of external pressures. There is a loss of the spirit of work, innovation, and has not encouraged changes that led to the explosion.

Research resources are declining in favor of spending on development. Marketing research budgets are reduced to increase the profitability of the company (Validova, 2014). Financiers are starting to play a more important role than people who are engaged in the marketing or research and development. Return of investment becomes the dominant indicator of execution plans.

\subsubsection{Stage of Recession}

During stage of the recession, the company does not create the necessary resources of self-preservation. For the stage of recession is characteristic: red tape, not always proved strategy, planning method of extrapolation, cumbersome control system, closed to new ideas, ineffective system of motivation.

The organizational model is the bureaucratic organization, composed of many units with low functional orientation. At this stage there is no focus on the result, no inclination to change, but there is a strict system of rules, regulations and procedures.

The organization is beginning to disintegrate. She is forced to accept the rigid system or upgrade, or cease to exist as an independent structure, being absorbed by another, stronger organization. However, the organization is able to be reborn. It can make a new team of managers responsible for the implementation of the programme of internal restructuring and institutional development. Here again begins the struggle for its survival.

\subsection{Development of the Organizational Structure of the Management on the Stages of the Life Cycle}

The life cycle phases greatly influence the type of organizational structure of the management. On the stage of introduction phase organizational structure has not yet formalized, at this stage, only the foundations of the future organizational structure. At this point, the organization must respond quickly to opportunities that for it provides the external environment. Therefore at this stage, the best would be a centralized management structure.

At the stage of growth the formalization of organizational structure also is low, because the structure is still in the stage of formation. The organization should remain flexible in order to conquer the market and maintain speed of increasing progress.

Stage of maturity phase is characterized by a fully formed management structure with formalized duties, the provisions of departments. At this point, many companies are busy diversification of business that generates to decentralization and use divisional organizational structure.

At the stage of saturation and recession the formalization of the structure reaches its peak. At the stage of maturity structure has the necessary degree of formalization. At the stage of saturation formalization becomes superfluous. Excessive formalization disturbs the development of organization as a result of superfluous rigidity of standards. Stringent standards hinder the implementation of changes in the activities of the organization. In the phase of the saturation the company could afford to maintain decentralized management structure, but in the stage of recession already not, because under question is the very survival of the organization. 
During stage of recession of the organizational model is the bureaucratic organization composed of many units with low functional orientation. At this stage there is no focus on the result, no inclination to change, but there is a strict system of rules, regulations and procedures.

If the organization is want to survive, it must quickly respond to external conditions quickly and clearly to make management decisions. This calls for centralizing structure.

The following table shows the optimal organizational structure types for the corresponding stage of the life cycle of the organization.

Table 1. Guidelines for choosing the type of organizational management structure depending on the stage of the life cycle of the organization

\begin{tabular}{|c|c|c|c|c|}
\hline \multirow{3}{*}{$\begin{array}{l}\text { Stage in the organizational life } \\
\text { cycle }\end{array}$} & \multicolumn{4}{|c|}{ Type of structure } \\
\hline & \multicolumn{2}{|c|}{ The degree of centralization } & $\begin{array}{l}\text { According to } \\
\text { formalization }\end{array}$ & degree \\
\hline & Centralized & $\begin{array}{l}\text { The } \\
\text { decentralizes }\end{array}$ & Bureaucratic & Organic \\
\hline Stage of introduction & + & & & + \\
\hline Stage of growth & + & & & + \\
\hline Stage of maturity & & + & + & \\
\hline Stage of saturation & & + & + & \\
\hline Stage of recession & & & & + \\
\hline
\end{tabular}

\section{Results}

Dependences between the transaction costs for the enterprises of the food-processing industry of the Russian Federation for the different stages of the organizational life cycle were built. Results of the analysis are presented in Figure 1.
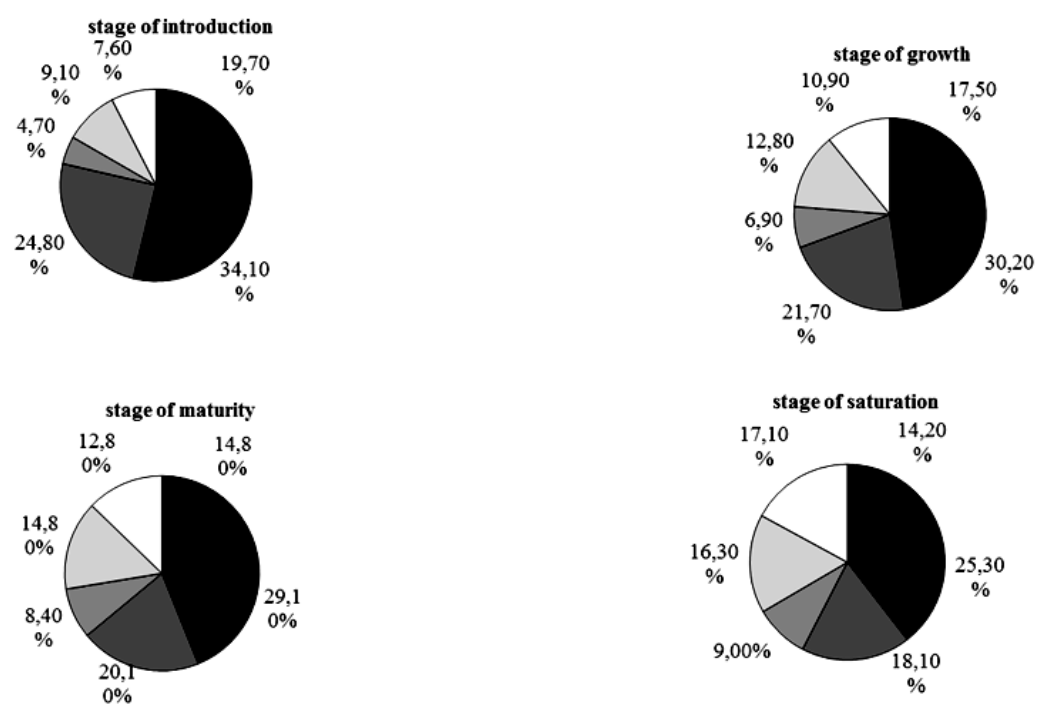

Figure 1. The structure of the transaction costs of food industry of the Russian Federation for the life cycle phases

According to drawing it is possible to draw the following conclusions. Search costs and information processing have a maximum size on Stage of introduction. It is caused by that at this stage; the organization is still only goes to the market. At that stage the organization is in the process of collecting information about the environment in which it will work and search for contractors. Late these costs tend to decrease, because the external environment is already well known. 
The costs of negotiating and contracting are also observed in the initial stages of development, because these stages are only beginning to linkages with suppliers and intermediaries and active consist contracts. At the following stages these expenses decrease a little as at these stages generally work is conducted with constant suppliers and clients. New communications occupy a smaller share in total of contractors.

The high level of costs to avoid opportunistic behaviors in the early stages organizational life cycle can be explained by the difficulty of monitoring the conduct of parties to contract. The organization is begin to work at the market in the initial stages of it organizational life cycle. For this reason it has not yet formed reliable connection with the permanent contractors. This leads to an increased risk losses from opportunistic behavior, as well as an increase in expenses for its prevention. This is because the high cost of forcing the other side to implement the terms of the contract. In the future, the company will work with both new and permanent contractors. This will result in some reduction of transaction costs.

Costs of collection, storage, and analysis of internal information on the enterprises of the food industry in general are not very large. This is because; this is usually small and medium-sized organizations. Large enterprises of food industry a bit. In large organizations, the costs of data collection, storage and analysis of internal organization will be slightly higher, but they still will not be too large. These costs are rising as they mature and aging. This is caused by the increase in the size of organization, the complexity of its structures, the accumulation the amount of data of internal information.

Costs of coordination also are raising in process the transition from one stage of the organizational life cycle to another. The reason for this is increase the complexity of the organizational structure of the management in the course of its growth of the organization and it's aging.

Cost control is growing up in the process of maturation of organization. It occurs, firstly, because takes place complexity growth of organizational structure of management. Secondly, increased costs of control are, because these costs include the costs of internal opportunistic behavior more. This is caused by the increasing bureaucratization of the organizational structure of the management at this stage. Bureaucratization of structure as a result brings cheat from staff, laze, and influence the higher management to achieve personal interests.

\section{Discussion}

Stages of organizational life cycle are closely connected with the features of the organizational structure of the management, as well as the nature and size of transaction costs. In process moving from one life cycle stage to another changes the strategic goals of the organization. This influences the type of organizational structure of the management. This is because the organizational structure of the management is to ensure the realization of the strategic goals of the organization. For this reason, there is a need to change the structure when you change the strategy of the organization.

Changing the organizational structure of the management changes the internal communications in organization and methods of work of the firm. This is reflected on the size of the transaction costs of the organization. For this reason, you need to analyze transaction costs at various stages of the organizational life cycle. This allows the leader to focus on problems and tasks, having relevance on the current stage in the life cycle of the organization

\section{Conclusion}

At various stages of the organizational life cycle have different characteristics.

Analysis of the level of transaction costs the organization allows to draw conclusions about the effectiveness of the functioning of the organization. Analysis of the structure of the transaction cost helps determine the bottlenecks in building the organizational structure of the management. To improve organizational efficiency, it is necessary to identify and eliminate unprofitable transactions. As a result of these activities is adjusted the organizational structure and management practices.

\section{References}

Adizes, I. (1979). Organizational Passages. Diagnosing and Treating Lifecycle Problems of Organization. Organizational Dynamics, 8(1), 3-25. http://dx.doi.org/10.1016/0090-2616(79)90001-9

Bagautdinova, N., Kumpilova, A., Boganchikova, I., \& Shakhnina, I. (2014). Peculiarities of Public Administration of Development of Small Business in Modern Conditions. Mediterranean Journal of Social Sciences, 5(12), 87-92.

Bagautdinova, N., Nayda, A., Hayrullin, B., \& Arzhantseva, N. (2014). Behaviour of Households on Financial Investments Market. Mediterranean Journal of Social Sciences, 5(12), 103-106. 
Cameron, K., \& Whetton, D. (1981). Perceptions of organizational effectiveness over organizational life cycles. Administrative Science Quarterly, 26(4), 525-544. http://dx.doi.org/10.2307/2392338

Drazin, R., \& Kazanjian, K. (1990). Research notes and communications: A reanalysis of Miler and Freisen's life cycle data. Strategic management journal, 11, 319-325. http://dx.doi.org/10.1002/smj.4250110407

Fakhrutdinova, E., Kolesnikova, J., Suleimanov, T., \& Khalikov, A. (2014). The interrelation of the problems of the youth labour market and the "brain drain". Life Science Journal, 11(6s), 473-477.

Greiner, L. (1972). Evolution and Revolution as Organizations Grow. Harvard Business Review, 50(4), 322-329.

Gupta, Y., \& Chin, D. (1994). Organizational life cycle: A review and proposed directions of research. Mid-Atlantic Journal of Business, 30(3), 269-294.

Gurianova, E. (2013). Increase of organizational effectiveness of management on the basis of optimization of transactional expenses. Inženernyj vestnik Dona. Retrieved June 28, 2014, from http://ivdon.ru/magazine /archive/n1y2013/1548

Hajrullina, A., \& Romadanova, O. (2014). Technique of measurement of value of the human capital as intangible asset of corporation. Life Science Journal, 11(6s), 518-521.

Hanks, S. (1990). The organization Life cycle: Integrating content and process. Journal of small business strategy, 1(1), 1-12.

Karasik, E., Yagudin, R., Leukhin, A., \& Zagidullina, V. (2014). Improvement of social policy towards the disabled in the Russian Federation. Life Science Journal, 11(6s), 478-481.

Kimberly, J. (1979). Issues in Creation of Organizations: Initiation, Innovation, and Institutionalization. Academy of Management Journal, 22, 437-457. http://dx.doi.org/10.2307/255737

Kirshin, I. (2014). Modeling the long-term trend of accumulation of knowledge. Life Science Journal, 11(6s), 482-486.

Lester, D., \& Parnell, J. (2008). Firm size and environmental scanning pursuits across organizational life cycle stages. Journal of Small Business and Enterprise Development, 15(3), 540-554. http://dx.doi.org/10.1108 /14626000810892337

Lester, D., Parnell, J., \& Carraher, A. (2003). Organizational Life Cycle: A Five-Stage Empirical Scale. The International Journal of Organizational Analysis, 11(4), 339-354. http://dx.doi.org/10.1108/eb028979

Miller, D., \& Friesen, P. (1984). A longitudinal study of the corporate life cycle. Management Science, 30(10), 1161-1183. http://dx.doi.org/10.1287/mnsc.30.10.1161

Mintzberg, H. (1984). Power and organizational life cycles. Academy of Management review, 9(2), 207-224.

Petrauskiene, A., \& Pundziene, A. (2004). Analysis of the dominant problems during different life cycle stages in rapidly growing enterprises. ISM University of Management and Economics, Kaunas, manuscript.

Sarkin, A., Bagautdinova, N., Averyanov, B., Novenkova, A., \& Arzhantseva, N. (2014). Assessment of Efficiency of Realization of Paternalistic Policy of Industrial Enterprises Development. Mediterranean Journal Of Social Sciences, 5(12), 9-14.

Serrasqueiro, Z., \& Ferrera, J. (2003). A taxonomic development of life-cycle stages: An approach of the firm acquisition capital. Beira Intrior University, Economic and management department, polo IV, Estrada do Sineiro, 6200-209 Covilha, Portugal.

Validova, A. (2014). Inflation targeting in developing countries: Perspectives for Russia. Life Science, 11(6s), 494-498.

Zhipeng, Y. (2006). New Methodology of Measuring Corporate Life-cycle Stages. Waltham: Brandeis University.

\section{Copyrights}

Copyright for this article is retained by the author(s), with first publication rights granted to the journal.

This is an open-access article distributed under the terms and conditions of the Creative Commons Attribution license (http://creativecommons.org/licenses/by/3.0/). 